\title{
Parkinson's Disease: Etiology, Neuropathology, and Pathogenesis
}

\author{
Antonina Kouli ${ }^{1} \bullet$ Kelli M. Torsney ${ }^{2,3} \bullet$ Wei-Li Kuan $^{1}$
}

${ }^{1}$ John van Geest Centre for Brain Repair, Department of Clinical Neurosciences, University of Cambridge, UK; ${ }^{2}$ Department of Medicine for the Elderly, Cambridge University Hospitals NHS Foundation Trust, UK; ${ }^{3}$ Clinical Gerontology Unit, Department of Public Health and Primary Care, University of Cambridge, UK

Author for Correspondence: Antonina Kouli, John van Geest Centre for Brain Repair, Department of Clinical Neurosciences, University of Cambridge, UK; E-mail: ak950@cam.ac.uk

Doi: http://dx.doi.org/10.15586/codonpublications.parkinsonsdisease.2018.ch1

\begin{abstract}
Parkinson's disease (PD) is a common neurodegenerative disorder. While a number of non-motor manifestations arise, the typical clinical features involve a movement disorder consisting of bradykinesia, resting tremor, and rigidity, with postural instability occurring at a later stage. The cause of PD is not known, but a number of genetic risk factors have now been characterized, as well as several genes which cause rare familial forms of PD. Environmental influences such as smoking, caffeine consumption, and pesticide exposure have been postulated to alter the risk of PD development, although the role of these remains unclear. The movement disorder arises due to the loss of dopaminergic neurons of the substantia nigra pars compacta, with the pathological hallmark being intracellular aggregates of $\alpha$-synuclein, in the form of Lewy bodies and Lewy neurites. Several processes have been implicated in PD, including mitochondrial dysfunction, defective protein clearance mechanisms, and neuroinflammation, but the way in which these factors interact remains incompletely understood.
\end{abstract}

In: Parkinson's Disease: Pathogenesis and Clinical Aspects. Stoker TB, Greenland JC (Editors). Codon Publications, Brisbane, Australia. ISBN: 978-0-9944381-6-4; Doi: http://dx.doi. org/10.15586/codonpublications.parkinsonsdisease.2018

Copyright: The Authors.

Licence: This open access article is licenced under Creative Commons Attribution 4.0 International (CC BY 4.0). https://creativecommons.org/licenses/by-nc/4.0/ 
Keywords: $\alpha$-synuclein; Lewy body; neurodegeneration; Parkinson's disease; pathogenesis

\section{INTRODUCTION}

Parkinson's disease (PD) is a complex progressive neurodegenerative disease characterized by tremor, rigidity, and bradykinesia, with postural instability appearing in some patients as the disease progresses. It was first described by James Parkinson in 1817 and further characterized by Jean-Martin Charcot, and our knowledge of $\mathrm{PD}$ is continuing to expand.

PD is the second most common neurodegenerative disease after Alzheimer's disease (AD) (1), with a prevalence of approximately 0.5-1\% among those 65-69 years of age, rising to $1-3 \%$ among persons 80 years of age and older $(2,3)$. With an aging population, both the prevalence and incidence of PD are expected to increase by more than $30 \%$ by 2030 (4), which will result in both direct and indirect costs on both society and the economy as a whole.

PD is pathologically characterized by the loss of nigrostriatal dopaminergic innervation, although neurodegeneration is not limited to only the nigral dopaminergic neurons but also involves cells located in other regions of the neural network. Such a widespread pathology makes PD a very heterogeneous disorder, and a reliable diagnostic test is not yet available. Currently, diagnosis is based on clinical symptoms with the criteria for a diagnosis requiring the presence of two of the following clinical features: resting tremor, bradykinesia, rigidity and/or postural instability. Clinical criteria, however, can only lead to a diagnosis of probable $\mathrm{PD}$, while a definitive diagnosis requires histopathological assessment, with the identification of $\alpha$-synuclein-containing Lewy bodies (LBs) or Lewy neurites.

Treatment predominantly focuses on symptomatic relief with drugs aiming to either restore the level of dopamine in the striatum or to act on striatal postsynaptic dopamine receptors. However, as dopamine is not the only neurotransmitter involved in PD, many other drugs are also being used to target specific symptoms, such as depression or dementia. Yet, further investigation on novel therapies to reduce the rate of neurodegeneration or even to replenish the loss of dopaminergic cells remains in the research setting, with some in the early stages of clinical trials. As our understanding of the pathogenesis of PD increases and more is learned about new therapeutic targets, the potential for the development of disease-modifying therapies is promising.

\section{CLINICAL FEATURES}

The clinical features historically associated with PD are the triad of motor symptoms, namely, tremor, rigidity, and bradykinesia, with postural instability often appearing as the disease progresses. However, PD is also associated with many non-motor symptoms, and these often precede the motor symptoms by years or even decades.

The pre-motor or prodromal phase of PD may start as early as 12-14 years before diagnosis (5). There is now a great deal of evidence supporting the fact that the disease 
may begin in the peripheral autonomic nervous system and/or the olfactory bulb, with the pathology then spreading through the central nervous system affecting the lower brainstem structures before involving the substantia nigra (6). This may thus explain the presence of hyposmia, constipation, and rapid eye movement sleep disorders in PD patients before motor symptoms begin. One study showed that patients with tremor, balance problems, depression, constipation, fatigue and urinary dysfunction at 5 years prior to diagnosis were more likely to develop PD than those without these symptoms (7). Additionally, individuals with constipation or tremor have a higher risk of developing PD over 10 years of follow-up (7).

There is increasing interest in this prodromal state of PD as it may be an ideal time point for therapeutic intervention. Many trials investigating potential therapies include patients with early PD, that is, those within 2 years of diagnosis, but even at this stage, significant dopaminergic neuron loss has already occurred (8) - therefore, it would be optimal for any future disease-modifying treatments to be initiated in the prodromal phase.

Clinical diagnosis of PD is based on the presence of bradykinesia in combination with a resting tremor or rigidity. Early symptoms generally present asymmetrically, with the absence of atypical symptoms (cerebellar signs, early severe autonomic dysfunction, vertical supranuclear palsies, or cortical sensory loss), which would be indicative of an alternative diagnosis (9). An asymmetric onset of symptoms and a good response to levodopa are supportive for a diagnosis of PD and are the two most important features to discriminate PD from other forms of Parkinsonism (9).

As the disease progresses, so does the severity of motor and non-motor symptoms. $\mathrm{PD}$ is a very heterogeneous disease and there have been attempts to subclassify the disease further. Although a consensus has yet to be met, one subclassification primarily based on clinical characteristics suggests two subtypes: a tremor dominant PD and a non-tremor dominant PD. A patient with tremor dominant PD predominantly lacks other motor symptoms and in general responds better to dopamine replacement therapy. On the other hand, a patient with a non-tremor dominant PD may have an akinetic-rigid syndrome and a postural instability disorder, as well as an increased incidence of non-motor features. The course of the disease and prognosis differs (10), and it has been postulated that the various subtypes have distinct pathogenesis and etiologies (11).

As the disease progresses, motor symptoms worsen over time, with the onset of further complications associated with long-term levodopa therapy. These include non-motor fluctuations, dyskinesias, and psychosis that are more difficult to manage. In an advanced disease stage, both motor and non-motor symptoms may become resistant to current medications. Postural instability and freezing of gait may lead to falls and fractures, while dementia and hallucinations can develop in some patients, which sometimes warrant care home placement.

Non-motor symptoms are common in early PD but also progress and become more challenging to manage. Early non-motor symptoms include impaired olfactory ability, autonomic dysfunction, pain, fatigue, sleep disorders, and cognitive and psychiatric disturbances. They have a significant impact on the patient's quality of life (12). Autonomic symptoms can be difficult to treat with orthostatic hypotension causing significant problems for patients. Urinary incontinence and constipation are common, and dementia occurs in $83 \%$ of patients with PD after 20 years of diagnosis (13). These non-motor symptoms contribute significantly to disability and poor quality of life and also strongly predict admission to care homes (14). 


\section{ETIOLOGY}

PD is a multifactorial disease, with both genetic and environmental factors playing a role. Age is the biggest risk factor for $\mathrm{PD}$, with the median age of onset being 60 years of age (15). The incidence of the disease rises with age to 93.1 (per 100,000 person-years) in age groups between 70 and 79 years $(16,17)$. Additionally, there are cross-cultural variations, with higher prevalence reported in Europe, North America, and South America compared with African, Asian and Arabic countries (1).

\section{Cigarette smoking}

Cigarette smoking has been extensively studied with respect to PD, with mostly consistent results. Most of the epidemiological reports are case-control studies showing a reduced risk of developing PD, with larger cohort studies also in agreement (18-20). A large meta-analysis including 44 case-control studies and 8 cohort studies from 20 countries showed an inverse correlation between smoking and PD, with a pooled relative risk of 0.39 for current smokers (21). Two other meta-analyses also reported an inverse correlation between smoking and PD, with a pooled odds ratio ranging from 0.23 to 0.70 , indicating a protective mechanism against PD $(22,23)$. They also reported an inverse correlation between the number of pack years, the number of years smoking and the risk of PD, with the risk of developing PD being significantly reduced in heavy or long-term smokers compared with nonsmokers (23).

The reasons underlying this associated reduced risk are not fully understood. Activation of nicotinic acetylcholine receptors on dopaminergic neurons by nicotine or selective agonists has been shown to be neuroprotective in experimental models of PD $(24,25)$. Nevertheless, nicotine can also stimulate the release of dopamine, which is involved in the reward mechanisms; it is therefore difficult to confirm whether smoking prevents PD or whether PD helps prevent the habitual use of cigarettes. As a result of a reduction in dopamine in patients with PD, patients may be less prone to addictive behaviours, and thus less likely to smoke. This hypothesis is supported by the fact that patients with prodromal PD and PD were able to give up smoking much easier than controls, suggesting this association could be due to the decreased responsiveness to nicotine (26).

\section{Caffeine}

Several studies have investigated the effect of caffeine on the development of PD and reported a reduced risk of developing PD among coffee drinkers. Caffeine is an adenosine $\mathrm{A}_{2 \mathrm{~A}}$ receptor antagonist, which is believed to be protective in PD (27) and has been shown to be neuroprotective in a mouse model of PD (28). It has been previously reported that there is a $25 \%$ risk reduction in developing PD among coffee drinkers (14). Two large prospective epidemiological studies $(27,29)$, as well as multiple retrospective studies (30), have also shown a reduced risk of developing PD with a relative risk ranging from 0.45 to 0.80 in coffee 
drinkers versus non-coffee drinkers. A meta-analysis including eight case-control studies and five cohort studies also showed a significantly reduced risk of developing PD in coffee drinkers (RR 0.69) (21). Regular tea drinkers also have been reported to have a lower risk of developing PD (29).

As with smoking, the causative role of caffeine in preventing PD remains to be established. Furthermore, there were differences noted between studies with respect to gender. In two cohort studies $(27,29)$, there was a strong inverse correlation between coffee and the development of PD in men, whereas in women this association was weaker. Additionally, in post-menopausal women, the effect of caffeine depended on whether the females were taking hormone replacement therapy including estrogens. As estrogen competitively inhibits caffeine metabolism, interactions between estrogen and caffeine may explain in part why PD risk is dependent on hormone replacement therapy in postmenopausal women $(31,32)$.

\section{Pesticides, herbicides, and heavy metals}

In 1983, 1-methyl-4-phenyl-1,2,3,6-tetrahydropyridine (MPTP) was first discovered to be associated with nigrostriatal degeneration when several people developed typical PD signs after injecting themselves with a drug contaminated with MPTP. MPTP is metabolized into the neurotoxin, MPP+ (1-methyl-4phenylpyridinium), which is a mitochondrial complex-I inhibitor that selectively damages dopaminergic cells in the substantia nigra $(32,33)$. The identification of MPTP as a cause of nigral degeneration led to the idea that PD could be caused by an environmental toxin. Since then, several studies have shown an association between pesticides and PD, with one case-control study showing an increased association with professional pesticide exposure in men and late-onset PD (odds ratio $[\mathrm{OR}] 2.2$ ) (34). Paraquat (a herbicide which is structurally very similar to $\mathrm{MPP}+$ ) (35) and rotenone (a pesticide) are also selective complex-I inhibitors and induce dopaminergic depletion in animal models of PD (36). The relationship between exposure to these chemicals and the risk of developing PD has been investigated in other epidemiological studies (37). It has also led to the study of surrogate markers, including the association of farming, drinking well water, and living in rural areas with PD risk. Welding and heavy metal exposure (e.g., iron, copper, lead, aluminum, and zinc) have also been investigated, but the relationship between these and PD remains inconclusive.

\section{Genetics}

Although PD is generally an idiopathic disorder, there is a minority of cases (10-15\%) that report a family history, and about 5\% have Mendelian inheritance (38). Furthermore, an individual's risk of PD is partially the product of as-yet poorly defined polygenic risk factors. The genes that have been found to potentially cause PD are assigned a "PARK" name in the order they were identified. To date, 23 PARK genes have been linked to PD. Mutations in the PARK genes demonstrate either autosomal dominant (e.g., SCNA, LRRK2, and VPS32) or autosomal recessive inheritance (e.g., PRKN, PINK1, and DJ-1) and are summarized in Table 1. The involvement of some of these genes has not been conclusively confirmed 
(PARK5, PARK11, PARK13, PARK18, PARK21, and PARK23), while others are considered risk factors (PARK3, PARK10, PARK12, PARK16, and PARK22) (39).

The numerically most important genetic risk factors predisposing to PD are mutations in GBA1, a gene encoding $\beta$-glucocerebrosidase-a lysosomal enzyme responsible for the hydrolysis of glucocerebrosides (see Chapter 3) (40). GBA1 mutations are known to cause Gaucher disease, which is the most common lysosomal storage disorder (41). Other genetic risk factors include the major histocompatibility complex, class II (HLA-DQB1) (42) and the gene encoding the protein tau, MAPT (43), among others.

\section{Autosomal dominant PD}

The first type of familial PD caused by a point mutation in the $\alpha$-synuclein gene (SNCA) was discovered in 1997 (44). Four additional point mutations, as well as gene duplication or triplication, have now been linked to autosomal dominant PD (45-50). However, these mutations are relatively rare. The most frequent autosomal dominant monogenic PD is caused by mutations in the gene encoding leucine-rich repeat kinase 2 (LRRK2). Six LRRK2 mutations have been confirmed as pathogenic (51), the most common of which is p.G2019S, estimated to account for $1 \%$ of sporadic and $4 \%$ of familial PD worldwide (51). More recent genetic studies have led to the discovery of additional mutations in other genes responsible for autosomal dominant PD, including VPS35 (Table 1).

\section{Autosomal recessive PD}

Autosomal recessive forms of PD typically present with an earlier onset than classical PD. Three of the PARK-designated genes causing autosomal recessive PD have been linked to mitochondrial homeostasis (PRKN, PINK1, and DJ-1). Specifically, the proteins PINKl and parkin (encoded by the PRKN gene) are both involved in the same mitochondrial quality control pathway, with PINKl recruiting parkin to dysfunctional mitochondria and thus initiating mitophagy (52). Mutations in PRKN are the most common cause of autosomal recessive familial PD, occurring in up to $50 \%$ of all early-onset cases (39). Finally, several of the autosomal recessive genes have been linked to atypical parkinsonism with variable features (Table 1), including ATP13A2 (PARK9), PLA2G6 (PARK14), FBX07 (PARK17), and SYNJ1 (PARK20) (53-56).

\section{NEUROPATHOLOGY OF PARKINSON'S DISEASE}

Macroscopically, the brain in idiopathic PD is often unremarkable with mild atrophy of the frontal cortex and ventricular dilation in some cases. The main distinctive morphological change in the PD brain is observed in transverse sections of the brainstem, where almost all cases present with loss of the darkly pigmented area in the substantia nigra pars compacta (SNpc) and locus coeruleus. This pigmentation loss directly correlates with the death of dopaminergic (DA) neuromelanin-containing neurons in the SNpc and noradrenergic neurons in the locus coeruleus (71). Cell death in the SNpc is mostly restricted to a specific 


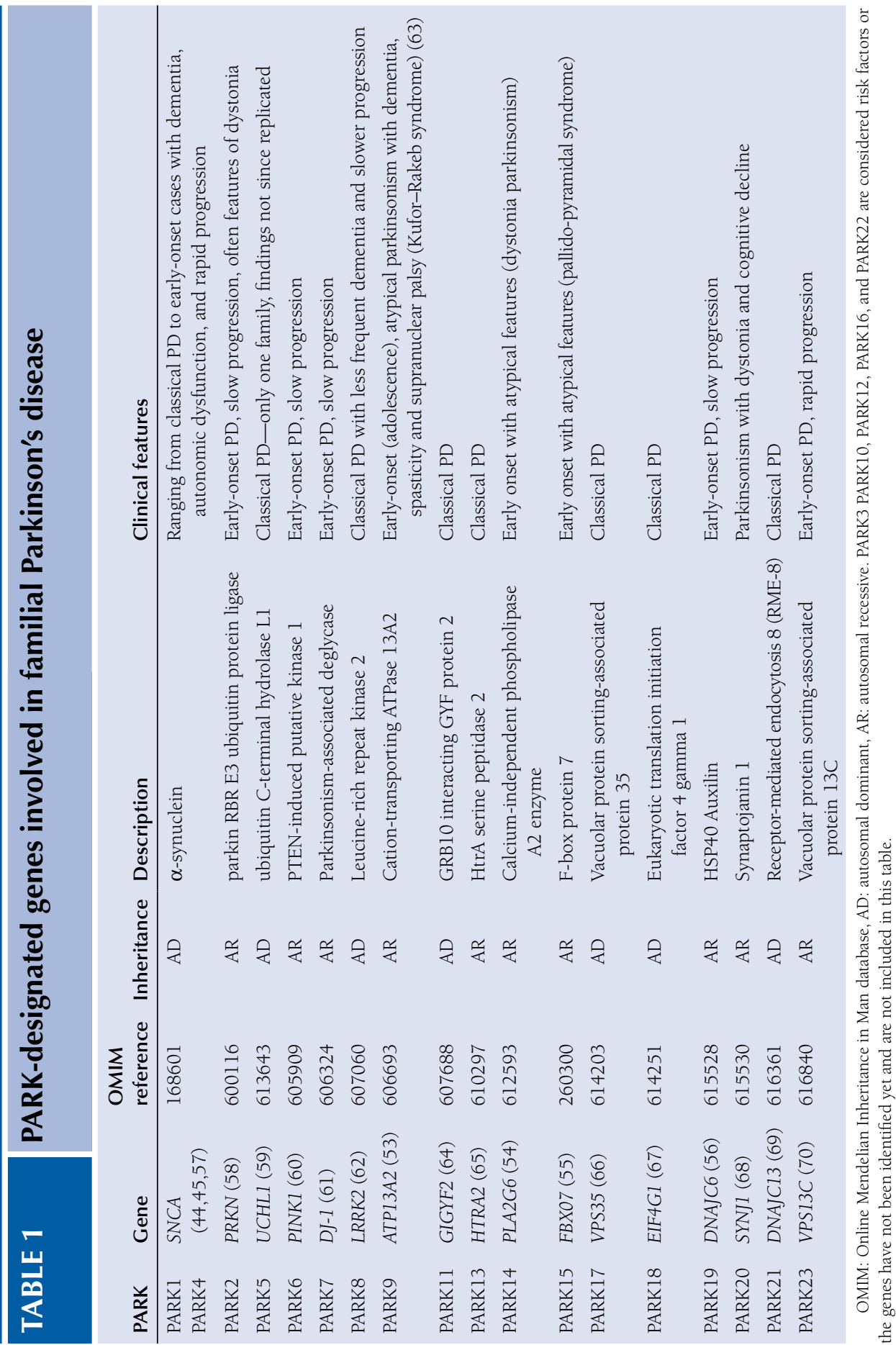


group of neuromelanin-containing dopaminergic neurons, namely the A9 neurons, while other neuronal and glial cell types are largely spared (Figure 1).

Quantitative morphometric studies in postmortem PD brains have calculated approximately 30\% loss of DA neurons in the SNpc by motor symptom onset, adjusting for age $(8,72-75)$. After the motor symptoms appear, nigral DA neuron loss increases up to $60 \%$ or higher and strongly correlates with the severity of motor features and disease duration $(8,76,77)$. The result of this remarkable cell loss is the denervation of the nigrostriatal pathway, leading to diminished dopamine levels in the striatum. The reduction of dopaminergic signaling is considered responsible for the appearance of the cardinal motor symptoms in PD. Recent work has shown that nerve cell death in the SNpc is preceded by the loss of axon terminals projecting to the striatum (77). Mechanistically, the early neuron and axon terminal loss observed in PD suggests a substantial preclinical stage that predates the onset of symptoms by several years.

Apart from the SNpc, widespread cell loss can be found in several subcortical nuclei, including the locus coereleus, the nucleus basalis of Meynert, the dorsal
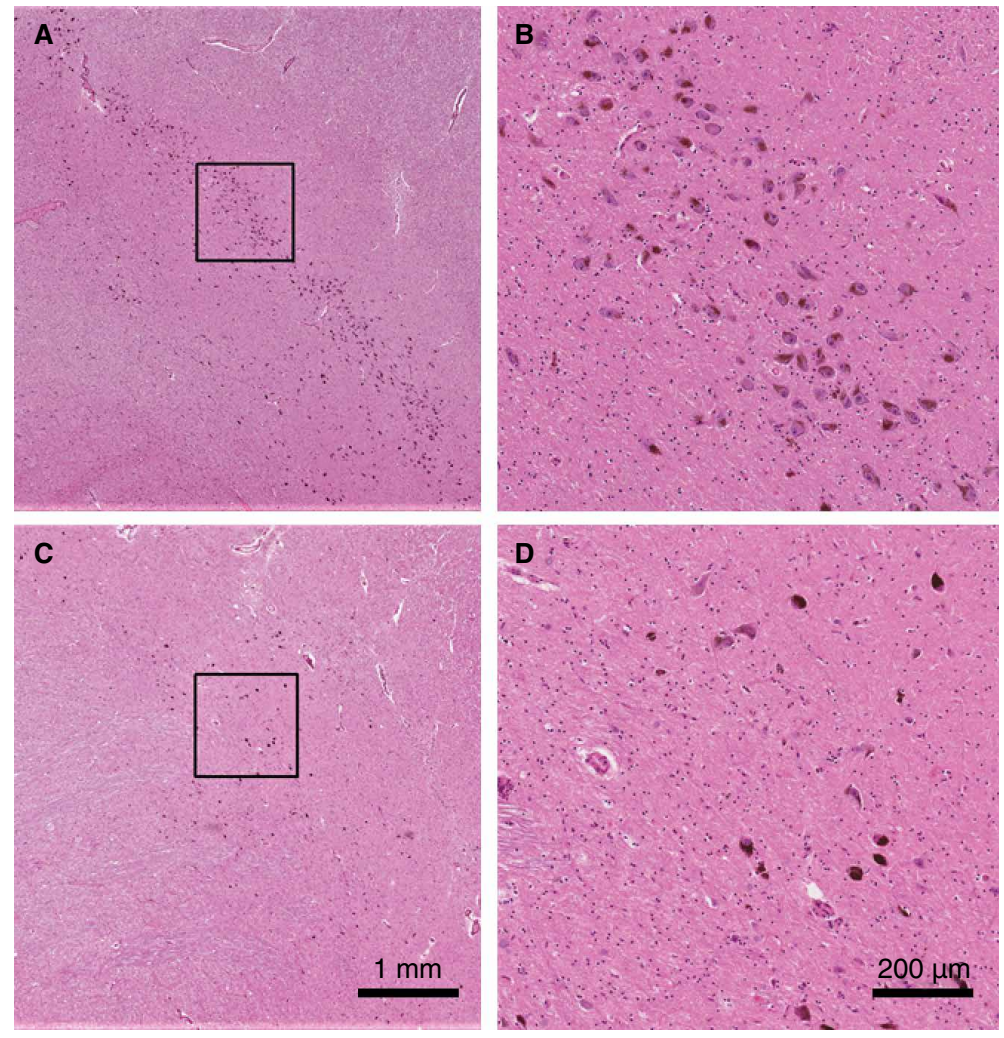

Figure 1 Coronal section at the level of the substantia nigra pars compacta (SNpc) in a control (A and B) and a PD brain (C and D) stained by hematoxylin and eosin. In both sections, the dark brown cells are the neuromelanin-containing dopaminergic (DA) neurons. Dopaminergic cell loss is evident in the SNpc of the PD brain. The squared areas in A and C are magnified in $B$ and $D$, respectively, to show a closer view of the darkly pigmented DA neurons. 
motor nucleus of the vagus nerve, the pedunculopontine nucleus, the raphe nuclei, and also the hypothalamus and the olfactory bulb (76). Multiple nondopaminergic neurotransmitter systems are affected, such as the cholinergic, adenosinergic, glutamatergic, GABAergic, noradrenergic, serotonergic, and histaminergic (78). Degeneration in those systems is thought to account for some of the non-motor symptoms of PD that do not respond well to dopamine replacement therapies (79). However, the precise pathological mechanisms underlying the non-motor symptoms in PD are still relatively unclear.

\section{Lewy body pathology}

Microscopically, the pathological hallmark of PD is the presence of abnormal cytoplasmic deposits within neuronal cell bodies which are immunoreactive for the protein $\alpha$-synuclein. These pathological protein aggregates are called Lewy bodies (LBs) and are often accompanied by dystrophic neurites (Lewy neurites), which are mostly axonal (80) (Figure 2A-2C).

LBs are intracytoplasmic inclusions consisting of a granular and fibrillar core with a surrounding halo (Figure 2A and 2B). The size of an LB can vary from 5 to $30 \mu \mathrm{m}$ in diameter, and more than one LB can be found inside a single neuron (81). Two LB types have been described in the literature: classical brainstem
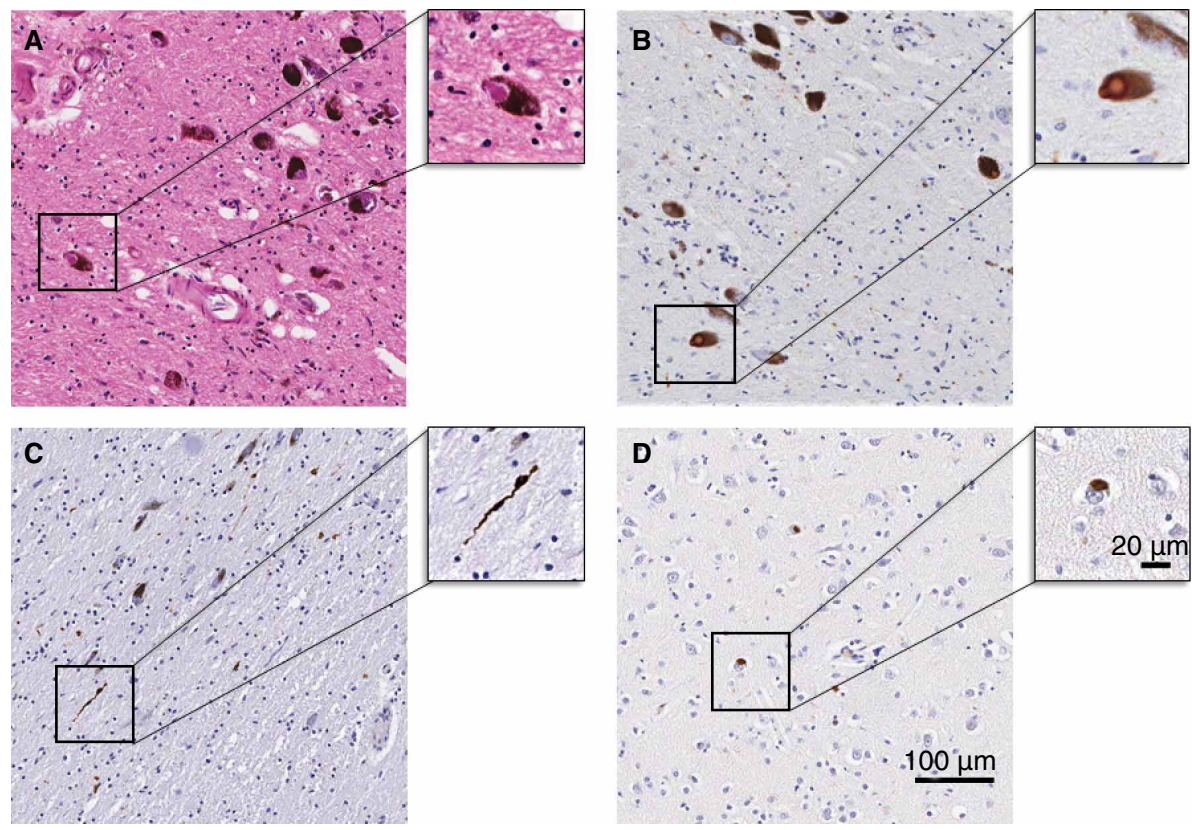

Figure 2 Examples of Lewy-pathology in the SNpc (A-C) and the prefrontal cortex (D) in coronal sections of a PD brain. (A) Typical brainstem Lewy body inside a neuromelanin-containing DA neuron in routine hematoxylin and eosin histological staining. Lewy neurites are not visible in this type of histological preparation. (B) Typical brainstem Lewy body with the characteristic halo, visualized by $\alpha$-synuclein immunohistochemistry, a much more sensitive method that can also reveal dystrophic Lewy neurites as seen in (C). (D) Cortical Lewy body, less well defined and without a halo. 
and cortical LBs (Figure 2B and 2D). Morphologically, the main difference is that cortical LBs have less distinct outlines, are usually smaller, and lack the halo. In the SN, structures that resemble cortical LBs are sometimes called "pale bodies" and are considered LB precursors.

The primary structural component of LBs is filamentous $\alpha$-synuclein (80), a protein ubiquitously expressed in the brain. In PD and other synucleinopathies, it acquires an amyloid-like filamentous structure and becomes abnormally phosphorylated and aggregated. The halo of an LB is primarily made up of $\alpha$-synuclein (82). Apart from $\alpha$-synuclein, the molecular components of an LB include a number of proteins, such as ubiquitin, tau, parkin, heat shock proteins (HSPs), oxidized/nitrated proteins, cytoskeletal proteins (such as neurofilaments, MAPs, and tubulin), proteasomal and lysosomal elements, and others (83).

\section{Braak staging}

The main staging system of PD pathology was introduced in 2003 by Braak and colleagues. This was based on the semiquantitative assessment of LB distribution, at postmortem, in a large autopsy series. This work revealed that LB pathology spreads rostrocaudally throughout the brain, in a chronologically predictable sequence (84). At Braak stages 1 and 2, LB lesions are mainly observed in the dorsal motor nucleus (IX/X), the reticular formation, and the anterior olfactory nucleus. At these stages, patients are considered asymptomatic or presymptomatic, although they may present with some early non-motor features, mainly autonomic (e.g., constipation), olfactory, and sleep-related dysfunctions $(85,86)$. As the disease progresses (Stage 3), the SNpc becomes involved, with LB pathology and neuronal loss being observed in melanized neurons. At this stage, the pathology also extends to the locus coeruleus and the amygdala, subsequently reaching the temporal limbic cortex (transentorhinal region) at Stage 4. During stages 3 and 4 , the typical clinical motor features begin to manifest. Finally, during stages 5 and 6 , the key feature is the involvement of the entire neocortex and high-order areas, including the prefrontal cortex and primary sensory and motor areas $(84,87)$. Clinically, this is thought to translate to severe PD with significant gait problems and dementia. The Braak hypothesis was later revised to propose that $\alpha$-synuclein-associated pathology may in fact be initiated in nasal and intestinal mucosal sites, specifically in the olfactory bulb and the enteric cell plexuses ("dual-hit hypothesis") (88).

Since its introduction in 2003, the Braak staging system has been a subject of controversy. Subsequent studies have shown that a proportion of PD brains do not appear to match this pattern $(89,90)$, while attempts to correlate Braak staging with clinical dysfunction were also unsuccessful (91). Another criticism of the Braak system is that it is based not on neuronal loss but on the distribution of Lewy-related pathology (92).

\section{$\alpha$-synuclein and Lewy body distribution outside the brain}

Phosphorylated $\alpha$-synuclein histopathology has also been observed outside the brain. Specifically, it is found in the spinal cord and cervical and thoracic sympathetic ganglia (93). Furthermore, $\alpha$-synuclein deposition is observed in 
several peripheral organs, including the retina, the uterus, the bladder, the skin, parts of the cardiovascular system (predominantly in the aorta and heart ventricles), and the gastrointestinal system, particularly in the submandibular gland, stomach, and the bowels $(94,95)$. This points to a significant involvement of the peripheral nervous system in $\mathrm{PD}$ and raises the question of whether $\alpha$-synuclein pathology originates in the brain or in the periphery. An epidemiological study from Denmark has revealed that a full truncal vagotomy is associated with a reduced risk of subsequent PD (96), leading to recent interest in the possible role of the gut-brain axis in the pathogenesis of PD (97).

\section{Interaction of $\alpha$-synuclein with other proteins}

Protein misfolding within particular brain areas is a shared feature among many neurodegenerative diseases, such as $\mathrm{AD}$ and $\mathrm{PD}$. Therefore, an umbrella term often used for these disorders is "proteinopathy." The type of protein and the characteristic distribution of the pathology is the significant attribute that defines each proteinopathy. Nevertheless, it is now becoming increasingly clear that there is often overlap between the different diseases and an interaction between the pathogenic, misfolded forms of proteins (98). One factor contributing to this phenomenon might be aging, and it is well established that abnormal protein accumulation can occur with age in the absence of neurodegenerative disease (99). Accumulating evidence now shows that within the context of PD there is a clear cross talk between different aggregated forms of proteins with distinct molecular pathways.

One such protein is tau, encoded by the MAPT gene. In pathological situations, tau can become abnormally hyperphosphorylated forming intracytoplasmic inclusions, called neurofibrillary tau tangles (NFTs). These aggregates are characteristic of $\mathrm{AD}$, together with amyloid- $\beta$ plaques. However, abnormal tau protein has been linked to PD as well. Specifically, postmortem studies have revealed a significant increase of tau hyperphosphorylation at Ser262 and Ser396/404 in the striatum of patients with PD and PD dementia (100). Animal studies have further added to this by showing that increased $\alpha$-synuclein expression can trigger tau hyperphosphorylation both in vitro and in vivo $(101,102)$. Furthermore, genome-wide association studies found a strong link between MAPT and the risk of PD (43), and subsequent longitudinal work showed that the $\mathrm{H1} / \mathrm{H} 1$ haplotype of MAPT is a strong predictor of early development of PD dementia (103).

Amyloid- $\beta$ has also been reported to act together with $\alpha$-synuclein. Cortical deposition of $\alpha$-synuclein has been associated with amyloid- $\beta$ plaque formation in a subgroup of PD patients (104). Furthermore, both NFTs and amyloid- $\beta$ senile plaques are widespread at postmortem in some, though not all, PD patients who develop cognitive dysfunction and dementia (105-108). Current literature seems to suggest that the manifestation of dementia in PD may be due to the convergence of both $\mathrm{PD}$ and $\mathrm{AD}$ pathology in the cortex, and that a combination of these pathologies is a better correlate of PD dementia (107). 


\section{PATHOGENESIS OF PARKINSON'S DISEASE}

A number of mechanisms have been implicated in PD pathogenesis, with $\alpha$-synuclein aggregation central to the development of the disease. Multiple other processes are thought to be involved, with several studies suggesting that abnormal protein clearance, mitochondrial dysfunction, and neuroinflammation play a role in the onset and progression of $\mathrm{PD}$. However, the relationship between these pathways remains unclear.

\section{$\alpha$-synuclein misfolding and aggregation}

Native $\alpha$-synuclein in the brain is mostly unfolded without a defined tertiary structure (109), although in aqueous solutions it can be present in stable tetramers that resist aggregation (110). Upon interaction with negatively charged lipids, such as the phospholipids that make up cell membranes, $\alpha$-synuclein folds into $\alpha$-helical structures through its $\mathrm{N}$-terminal (111). In PD, $\alpha$-synuclein adopts a $\beta$-sheet-rich amyloid-like structure that is prone to aggregate. Indeed, misfolded $\alpha$-synuclein is found within LBs as $5-10 \mathrm{~nm}$ long filaments. Several mechanisms have been proposed for the conformational changes that lead to abnormal $\alpha$-synuclein aggregation, including serine 129 phosphorylation, ubiquitination, and C-terminal truncation $(112,113)$. Hence, different species of $\alpha$-synuclein are found in the PD brain, including unfolded monomers, soluble oligomers, protofibrils, and high molecular weight insoluble fibrils (114).

Recent studies in rodents indicated that the most neurotoxic $\alpha$-synuclein species is the early oligomeric form, rather than the mature insoluble fibrils $(115,116)$. The increased toxicity of these oligomers, as opposed to the fibrillary $\alpha$-synuclein, was validated in cell-based assays (115). The oligomeric species of $\alpha$-synuclein are capable of "seeding" and accelerating abnormal protein aggregation and Danzer et al. (2011) proposed that this might be the mechanism underlying the spread of $\alpha$-synuclein pathology in the brain (117).

\section{Mitochondrial dysfunction}

Mitochondrial dysfunction is considered a key element in the pathogenesis of both idiopathic and familial PD (118). Early postmortem studies in the SNpc of PD brains reported a deficiency of the mitochondrial complex-I, which is a vital component of the electron transport chain. These data provided one of the first direct links between mitochondrial dysfunction and PD (119). Complex-I deficiency was also found in skeletal muscle and platelets of PD patients compared to healthy subjects $(120,121)$. Further evidence arose by the discovery that abuse of the substance MPTP caused permanent Parkinsonian symptoms (34), with postmortem examination revealing dopaminergic cell loss (122). Follow-up studies showed that MPTP when oxidized is taken up by DA neurons and leads to complex-I inhibition (123). Other toxins and pesticides that impair mitochondrial complex-I activity, like rotenone and paraquat, also cause a Parkinsonian phenotype and DA cell loss in animals, and potentially in humans (124). Defects in the mitochondrial complex-I may be crucial in driving DA cell death due to energy depletion (118).

Another major clue pointing to the role of mitochondria in PD pathogenesis is that many of the known genes that cause familial PD play a role in 
mitochondrial homeostasis. One example is the involvement of PINKl and parkin (PARK2 and PARK6, respectively), both of which are vital components of the pathway that regulates the removal of dysfunctional mitochondria, a process called mitophagy (52). Loss-of-function mutations in either gene lead to impaired mitochondrial quality control and cause autosomal recessive PD $(58,125)$.

Finally, $\alpha$-synuclein by itself is known to interfere with mitochondrial function. For instance, $\alpha$-synuclein can interact with the mitochondrial membrane and accumulate inside the organelles. This leads to the damage of complex-I activity, ultimately resulting in mitochondrial dysfunction and increased oxidative stress $(126,127)$. A more recent study reported an interaction between oligomeric (but not monomeric or fibrillar) $\alpha$-synuclein and the mitochondrial receptor TOM20 (128). This interaction resulted in impairment of the mitochondrial protein import machinery, reduced respiration, and led to excessive production of reactive oxygen species (ROS).

\section{Dysfunctional protein clearance systems}

There are two central protein clearance systems within cells responsible for the removal of dysfunctional proteins: the ubiquitin-proteasome system (UPS) and the autophagy-lysosome pathway. The UPS is primarily responsible for breaking down abnormal proteins, and it does so by "tagging" them with ubiquitin and transporting them to the proteasome for degradation. The autophagy-lysosome pathway is divided into three constituents: macroautophagy, microautophagy, and chaperone-mediated autophagy (CMA). Briefly, in macroautophagy, intracellular components, including cytosolic proteins, are engulfed by the autophagosome, which then fuses with the lysosome, leading to the breakdown of its contents. On the other hand, in microautophagy, the lysosome alone engulfs and destroys cytoplasmic components. CMA is a more selective process, whereby molecular chaperones target specific proteins and transport them to the lysosome for degradation (129). Monomeric $\alpha$-synuclein is generally cleared by both the UPS and the autophagy-lysosome pathway (130), and damage in either of their machineries is implicated in the pathogenesis of PD by contributing to the accumulation of defective proteins, in particular soluble misfolded $\alpha$-synuclein $(131,132)$.

\section{Ubiquitin-proteasome system}

Proteasomal abnormalities are a shared feature among many proteinopathies, that is, neurodegenerative diseases characterized by abnormal protein accumulation (133). Evidence of such abnormalities in PD was first provided by postmortem studies in the SNpc, where the catalytic activity of the UPS was found substantially reduced compared to healthy brains (134). The same findings were later reported in peripheral blood mononuclear cells of PD but not in healthy individuals (135). Apart from diminished activity, a lower expression of different proteasomal components has also been identified in the SNpc of PD brains. Specifically, the $20 S$ proteasome $\alpha$-subunit (136) and other molecules involved in the normal function of the UPS, like PA700 and PA28 (proteasome activators), are reduced (137). Additional evidence is provided from genetic studies and the discovery that two of the PARK genes linked to monogenic PD encode proteins 
involved in UPS function, namely, parkin (PARK2; E3 ubiquitin ligase) $(58,138)$ and UCH-Ll (PARK5; Ubiquitin C-terminal hydrolase) (59).

Following on from findings in human PD, altered proteasome activity was observed in different disease models. Marmosets injected with the toxin MPTP had diminished enzyme activity in the UPS, in addition to decreased levels of the 265 subunit components (139). In a second set of experiments, the same group showed that pharmacological inhibition of the proteasome in wild-type rats leads to dopaminergic cell death (140). Similarly, Bedford and colleagues using transgenic mice with proteasomal defects (knockout for $26 \mathrm{~S}$ proteasome regulatory subunit 4) showed dopaminergic cell degeneration and observed LB-like inclusions in the brain, which however lacked the dense core of classical human LBs, and it is unclear whether they contained aggregated $\alpha$-synuclein (141). Nevertheless, all these studies show that dysfunction of protein turnover can result in neuronal cell death, thus providing a potential pathogenic mechanism for PD.

\section{Autophagy- lysosome system}

Similar to findings in the UPS system, numerous lysosomal and autophagy-related components are malfunctioning or differentially expressed in PD. In nigral neurons of PD brains, the levels of the autophagosome marker LC3-II were increased, suggesting an accumulation of autophagic vacuoles $(142,143)$. In contrast, vital proteins of lysosomal membranes (LAMP1 and LAMP2A), and several molecular chaperones from the heat-shock protein family (such as hsc70 and hsp35) were found to be decreased at postmortem examination $(144,145)$. Furthermore, of particular note is the discovery of a point mutation in the gene of the lysosomal protein ATP13A2 (PARK9), leading to an autosomal recessive atypical Parkinsonian syndrome, referred to as Kufor-Rakeb syndrome (63). Point mutations in two more PARK genes impair the function of either parkin (PARK2) (58) or PINK1 (PARK6) (60), both of which are involved in the autophagic turnover of mitochondria (52). Additionally, the emergence of GBA1 mutations, which result in dysfunction of the lysosome-autophagy system, as a strong genetic risk factor for PD adds weight to the idea that this system is important in the development of PD (see Chapter 3). These studies lend support to the hypothesis that malfunction in the autophagy-lysosome pathway may be contributing to the pathogenesis of PD.

\section{Neuroinflammation}

Postmortem brain studies have described microglial and complement activation, T-lymphocyte infiltration, and increased concentration of pro-inflammatory cytokines in the SNpc and striatum of PD patients compared to healthy individuals (146-149). Furthermore, positron emission tomography (PET) neuroimaging with the $\left[{ }^{11} \mathrm{C}\right]-\mathrm{PK} 11195$ radioligand has demonstrated increased microglial activation early on in PD in the brainstem, basal ganglia, and frontotemporal cortices, with added involvement of the parietal and occipital cortices in patients with PD dementia, compared to healthy subjects $(150,151)$.

While initially thought to be a secondary phenomenon, there is now evidence that inflammatory responses can by themselves contribute to disease pathogenesis. It has been demonstrated in early studies with rodent models of PD (6-hydroxydopamine and MPTP) that inhibition of microglial activation with 
minocycline pre- and post-neurotoxic insult led to a significant attenuation of DA cell death in the SNpc, suggesting that microglia-induced inflammatory processes may be contributing to the degeneration of these cells $(152,153)$. There is also a plethora of evidence suggesting that $\alpha$-synuclein can directly trigger microglial activation and initiate inflammatory processes. For instance, in primary cultures, $\alpha$-synuclein mediates a dose-dependent activation of microglia (154).

Genetic clues suggesting that immune activation might contribute etiologically in PD come from the identification of a strong association between the human leucocyte antigen (HLA) class II region (a key molecule of the immune system) and the risk of developing PD (155) - a finding that was later confirmed in genome-wide association studies (42). Additionally, extensive epidemiological studies suggest a decreased PD risk with regular use of the nonsteroidal anti-inflammatory drug ibuprofen (156). Finally, recent data showed that in PD patients at diagnosis a more 'pro-inflammatory' immune marker profile in the serum is associated with a faster motor symptom progression and more impaired cognitive function (157).

Regardless of whether neuroinflammatory responses are a direct trigger of neurodegeneration in PD or are activated as a response to neuronal damage, it is now becoming clear that the engagement of the immune system can initiate a vicious cycle, thereby exacerbating neuronal dysfunction. Hence, manipulation of the immune system remains a promising topic for disease-modifying therapies.

\section{CONCLUSION}

PD is a complex neurodegenerative condition, for which the etiology and pathogenic mechanisms remain incompletely understood. While a small proportion of PD patients have a monogenic cause for their disease, the majority of cases probably are not associated with a specific genetic abnormality. Instead, it is likely that the risk of PD is in part, determined by a combination of polygenic susceptibility factors. Environmental influences may also contribute to PD risk, although the relationship between the development of the disease and factors such as smoking, caffeine, and pesticide exposure continues to be poorly understood. Pathologically, the movement disorder occurs due to loss of dopaminergic neurons in the SNpc, with a number of other brain regions also being involved. The histopathological hallmark of PD are LBs, which predominantly contain aggregated $\alpha$-synuclein, but it is not clear how these may result in neurodegeneration. Understanding these pathogenic processes can allow for the identification of novel therapeutic targets, and, hopefully, the development of disease-modifying treatments in the future.

Conflict of interest: The authors declare no potential conflicts of interest with respect to research, authorship and/or publication of this manuscript.

Copyright and permission statement: To the best of our knowledge, the materials included in this chapter do not violate copyright laws. All original sources have been appropriately acknowledged and/or referenced. Where relevant, appropriate permissions have been obtained from the original copyright holder(s).

Acknowledgment: The authors acknowledge the financial support from the following organizations: The Rosetrees Trust and the Onassis Foundation. 


\section{REFERENCES}

1. Kalia LV, Lang AE. Parkinson's disease. Lancet. 2015 Aug 29;386(9996):896-912. https://doi. org/10.1016/S0140-6736(14)61393-3

2. Tanner CM, Goldman SM. Epidemiology of Parkinson's disease. Neurol Clin. 1996 May;14(2): 317-35. https://doi.org/10.1016/S0733-8619(05)70259-0

3. Nussbaum RL, Ellis CE. Alzheimer's disease and Parkinson's disease. N Engl J Med. 2003 Apr 3; 348(14):1356-64. https://doi.org/10.1056/NEJM2003ra020003

4. Chen RC, Chang SF, Su CL, Chen TH, Yen MF, Wu HM, et al. Prevalence, incidence, and mortality of PD: A door-to-door survey in Ilan county, Taiwan. Neurology. 2001 Nov 13;57(9):1679-86. https:// doi.org/10.1212/WNL.57.9.1679

5. Postuma RB, Aarsland D, Barone P, Burn DJ, Hawkes CH, Oertel W, et al. Identifying prodromal Parkinson's disease: Pre-motor disorders in Parkinson's disease. Mov Disord. 2012 Apr 15;27(5): 617-26. https://doi.org/10.1002/mds.24996

6. Katzenschlager R, Head J, Schrag A, Ben-Shlomo Y, Evans A, Lees AJ, et al. Fourteen-year final report of the randomized PDRG-UK trial comparing three initial treatments in PD. Neurology. 2008 Aug 12; 71(7):474-80. https://doi.org/10.1212/01.wnl.0000310812.43352.66

7. Schrag A, Horsfall L, Walters K, Noyce A, Petersen I. Prediagnostic presentations of Parkinson's disease in primary care: A case-control study. Lancet Neurol. 2015 Jan;14(1):57-64. https://doi.org/10.1016/ S1474-4422(14)70287-X

8. Ma SY, Röyttä M, Rinne JO, Collan Y, Rinne UK. Correlation between neuromorphometry in the substantia nigra and clinical features in Parkinson's disease using disector counts. J Neurol Sci. 1997 Oct 3;151(1):83-7. https://doi.org/10.1016/S0022-510X(97)00100-7

9. Williams-Gray CH, Worth PF. Parkinson's disease. Medicine. 2016 Sep 1;44(9):542-6. https://doi. org/10.1016/j.mpmed.2016.06.001

10. Jankovic J, McDermott M, Carter J, Gauthier S, Goetz C, Golbe L, et al. Variable expression of Parkinson's disease: A base-line analysis of the DATATOP cohort. The Parkinson Study Group. Neurology. 1990 Oct;40(10):1529-34. https://doi.org/10.1212/WNL.40.10.1529

11. Marras C, Lang A. Parkinson's disease subtypes: Lost in translation? J Neurol Neurosurg Psychiatr. 2013;84(4):409-415. https://doi.org/10.1136/jnnp-2012-303455

12. Martinez-Martin P, Rodriguez-Blazquez C, Kurtis MM, Chaudhuri KR, NMSS Validation Group. The impact of non-motor symptoms on health-related quality of life of patients with Parkinson's disease. Mov Disord. 2011 Feb 15;26(3):399-406. https://doi.org/10.1002/mds.23462

13. Iranzo A, Tolosa E, Gelpi E, Molinuevo JL, Valldeoriola F, Serradell M, et al. Neurodegenerative disease status and post-mortem pathology in idiopathic rapid-eye-movement sleep behaviour disorder: An observational cohort study. Lancet Neurol. 2013 May;12(5):443-53. https://doi.org/10.1016/ S1474-4422(13)70056-5

14. Noyce AJ, Bestwick JP, Silveira-Moriyama L, Hawkes CH, Giovannoni G, Lees AJ, et al. Meta-analysis of early nonmotor features and risk factors for Parkinson disease. Ann Neurol. 2012 Dec;72(6): 893-901. https://doi.org/10.1002/ana.23687

15. Lees AJ, Hardy J, Revesz T. Parkinson's disease. Lancet. 2009 Jun 13;373(9680):2055-66. https://doi. org/10.1016/S0140-6736(09)60492-X

16. de Rijk MC, Breteler MM, Graveland GA, Ott A, Grobbee DE, van der Meché FG, et al. Prevalence of Parkinson's disease in the elderly: The Rotterdam Study. Neurology. 1995 Dec;45(12):2143-6. https:// doi.org/10.1212/WNL.45.12.2143

17. Bower JH, Maraganore DM, McDonnell SK, Rocca WA. Incidence and distribution of parkinsonism in Olmsted County, Minnesota, 1976-1990. Neurology. 1999 Apr 12;52(6):1214-20. https://doi. org/10.1212/WNL.52.6.1214

18. Grandinetti A, Morens DM, Reed D, MacEachern D. Prospective study of cigarette smoking and the risk of developing idiopathic Parkinson's disease. Am J Epidemiol. 1994 Jun 15;139(12):1129-38. https://doi.org/10.1093/oxfordjournals.aje.al16960

19. Paganini-Hill A. Risk factors for Parkinson's disease: The leisure world cohort study. Neuroepidemiology. 2001 May;20(2):118-24. https://doi.org/10.1159/000054770 
20. Hernán MA, Zhang SM, Rueda-deCastro AM, Colditz GA, Speizer FE, Ascherio A. Cigarette smoking and the incidence of Parkinson's disease in two prospective studies. Ann Neurol. 2001 Dec;50(6): 780-6. https://doi.org/10.1002/ana.10028

21. Hernán MA, Takkouche B, Caamaño-Isorna F, Gestal-Otero JJ. A meta-analysis of coffee drinking, cigarette smoking, and the risk of Parkinson's disease. Ann Neurol. 2002 Sep;52(3):276-84. https:// doi.org/10.1002/ana.10277

22. Ritz B, Ascherio A, Checkoway H, Marder KS, Nelson LM, Rocca WA, et al. Pooled analysis of tobacco use and risk of Parkinson disease. Arch Neurol. 2007 Jul;64(7):990-7. https://doi.org/10.1002/ ana. 10277

23. Breckenridge CB, Berry C, Chang ET, Jr RLS, Mandel JS. Association between Parkinson's disease and cigarette smoking, rural living, well-water consumption, farming and pesticide use: Systematic review and meta-analysis. PLoS One. 2016 Apr 7;11(4):e0151841. https://doi.org/10.1371/journal. pone. 0151841

24. Bordia T, McGregor M, Papke RL, Decker MW, McIntosh JM, Quik M. The $\alpha 7$ nicotinic receptor agonist ABT-107 protects against nigrostriatal damage in rats with unilateral 6-hydroxydopamine lesions. Exp Neurol. 2015 Jan;263:277-84. https://doi.org/10.1016/j.expneurol.2014.09.015

25. Srinivasan R, Henley BM, Henderson BJ, Indersmitten T, Cohen BN, Kim CH, et al. Smoking-relevant nicotine concentration attenuates the unfolded protein response in Dopaminergic neurons. J Neurosci. 2016 Jan 6;36(1):65-79. https://doi.org/10.1523/JNEUROSCI.2126-15.2016

26. Ritz B, Lee P-C, Lassen CF, Arah OA. Parkinson disease and smoking revisited: Ease of quitting is an early sign of the disease. Neurology. 2014 Oct 14;83(16):1396-402. https://doi.org/10.1212/ WNL.0000000000000879

27. Ross GW, Abbott RD, Petrovitch H, Morens DM, Grandinetti A, Tung KH, et al. Association of coffee and caffeine intake with the risk of Parkinson disease. JAMA. 2000 May 24;283(20):2674-9. https:// doi.org/10.1001/jama.283.20.2674

28. Chen JF, Xu K, Petzer JP, Staal R, Xu YH, Beilstein M, et al. Neuroprotection by caffeine and A(2A) adenosine receptor inactivation in a model of Parkinson's disease. J Neurosci. 2001 May 15;21(10):RC143. https://doi.org/10.1523/JNEUROSCI.21-10-j0001.2001

29. Ascherio A, Zhang SM, Hernán MA, Kawachi I, Colditz GA, Speizer FE, et al. Prospective study of caffeine consumption and risk of Parkinson's disease in men and women. Ann Neurol. 2001 Jul;50(1):56-63. https://doi.org/10.1002/ana.1052

30. Benedetti MD, Bower JH, Maraganore DM, McDonnell SK, Peterson BJ, Ahlskog JE, et al. Smoking, alcohol, and coffee consumption preceding Parkinson's disease: A case-control study. Neurology. 2000 Nov 14;55(9):1350-8. https://doi.org/10.1212/WNL.55.9.1350

31. Ascherio A, Weisskopf MG, O'Reilly EJ, McCullough ML, Calle EE, Rodriguez C, et al. Coffee consumption, gender, and Parkinson's disease mortality in the cancer prevention study II cohort: The modifying effects of estrogen. Am J Epidemiol. 2004 Nov 15;160(10):977-84. https://doi. org/10.1093/aje/kwh312

32. Xu K, Xu Y, Brown-Jermyn D, Chen J-F, Ascherio A, Dluzen DE, et al. Estrogen prevents neuroprotection by caffeine in the mouse 1-methyl-4-phenyl-1,2,3,6-tetrahydropyridine model of Parkinson's disease. J Neurosci. 2006 Jan 11;26(2):535-41. https://doi.org/10.1523/JNEUROSCI.3008-05.2006

33. Langston JW, Ballard P, Tetrud JW, Irwin I. Chronic Parkinsonism in humans due to a product of meperidine-analog synthesis. Science. 1983 Feb 25;219(4587):979-80.

34. Elbaz A, Clavel J, Rathouz PJ, Moisan F, Galanaud J-P, Delemotte B, et al. Professional exposure to pesticides and Parkinson disease. Ann Neurol. 2009 Oct;66(4):494-504. https://doi.org/10.1002/ana.21717

35. Di Monte D, Sandy MS, Ekström G, Smith MT. Comparative studies on the mechanisms of paraquat and 1-methyl-4-phenylpyridine (MPP+) cytotoxicity. Biochem Biophys Res Comm. 1986 May 29;137(1):303-9.

36. Betarbet R, Sherer TB, MacKenzie G, Garcia-Osuna M, Panov AV, Greenamyre JT. Chronic systemic pesticide exposure reproduces features of Parkinson's disease. Nat Neurosci. 2000 Dec;3(12):1301-6. https://doi.org/10.1038/81834

37. Tanner CM, Kamel F, Ross GW, Hoppin JA, Goldman SM, Korell M, et al. Rotenone, Paraquat, and Parkinson's disease. Environ Health Perspect. 2011 Jun;119(6):866-72. https://doi.org/10.1289/ ehp.1002839 
38. Deng H, Wang P, Jankovic J. The genetics of Parkinson disease. Ageing Res Rev. 2018 Mar 1;42:72-85. https://doi.org/10.1016/j.arr.2017.12.007

39. Schulte C, Gasser T. Genetic basis of Parkinson's disease: Inheritance, penetrance, and expression. Appl Clin Genet. 2011 Jun 1;4:67-80.

40. Nichols WC, Pankratz N, Marek DK, Pauciulo MW, Elsaesser VE, Halter CA, et al. Mutations in GBA are associated with familial Parkinson disease susceptibility and age at onset. Neurology. 2009 Jan 27;72(4):310-16. https://doi.org/10.1212/01.wnl.0000327823.81237.dl

41. Sidransky E, Lopez G. The link between the GBA gene and parkinsonism. Lancet Neurol. 2012 Nov;11(11):986-98. https://doi.org/10.1016/S1474-4422(12)70190-4

42. Nalls MA, Pankratz N, Lill CM, Do CB, Hernandez DG, Saad M, et al. Large-scale meta-analysis of genome-wide association data identifies six new risk loci for Parkinson's disease. Nat Genet. 2014 Jul 27;46(9):989-93. https://doi.org/10.1038/ng.3043

43. Simón-Sánchez J, Schulte C, Bras JM, Sharma M, Gibbs JR, Berg D, et al. Genome-wide association study reveals genetic risk underlying Parkinson's disease. Nat Genet. 2009 Dec;41(12):1308-12. https://doi.org/10.1038/ng.487

44. Polymeropoulos MH, Lavedan C, Leroy E, Ide SE, Dehejia A, Dutra A, et al. Mutation in the alphasynuclein gene identified in families with Parkinson's disease. Science. 1997 Jun 27;276(5321):2045-7. https://doi.org/10.1126/science.276.5321.2045

45. Singleton AB, Farrer M, Johnson J, Singleton A, Hague S, Kachergus J, et al. $\alpha$-Synuclein locus triplication causes Parkinson's disease. Science. 2003 Oct 31;302(5646):841. https://doi.org/10.1126/ science. 1090278

46. Zarranz JJ, Alegre J, Gómez-Esteban JC, Lezcano E, Ros R, Ampuero I, et al. The new mutation, E46K, of alpha-synuclein causes Parkinson and Lewy body dementia. Ann Neurol. 2004 Feb;55(2):164-73. https://doi.org/10.1002/ana.10795

47. Chartier-Harlin M-C, Kachergus J, Roumier C, Mouroux V, Douay X, Lincoln S, et al. Alpha-synuclein locus duplication as a cause of familial Parkinson's disease. Lancet. 2004 Oct 25;364(9440):1167-9. https://doi.org/10.1016/S0140-6736(04)17103-1

48. Krüger R, Kuhn W, Müller T, Woitalla D, Graeber M, Kösel S, et al. Ala30Pro mutation in the gene encoding alpha-synuclein in Parkinson's disease. Nat Genet. 1998 Feb;18(2):106-8. https://doi. org/10.1038/ng0298-106

49. Appel-Cresswell S, Vilarino-Guell C, Encarnacion M, Sherman H, Yu I, Shah B, et al. Alpha-synuclein p.H50Q, a novel pathogenic mutation for Parkinson's disease. Mov Disord. 2013 Jun;28(6):811-13. https://doi.org/10.1002/mds.25421

50. Lesage S, Anheim M, Letournel F, Bousset L, Honoré A, Rozas N, et al. G51D $\alpha$-synuclein mutation causes a novel Parkinsonian-pyramidal syndrome. Ann Neurol. 2013 Mar 22;73(4):459-71. https:// doi.org/10.1002/ana.23894

51. Healy DG, Falchi M, O'Sullivan SS, Bonifati V, Durr A, Bressman S, et al. Phenotype, genotype, and worldwide genetic penetrance of LRRK2-associated Parkinson's disease: A case-control study. Lancet Neurol. 2008 Jul;7(7):583-90. https://doi.org/10.1016/S1474-4422(08)70117-0

52. Pickrell AM, Youle RJ. The roles of PINK1, Parkin and mitochondrial fidelity in Parkinson's disease. Neuron. 2015 Jan 21;85(2):257-73. https://doi.org/10.1016/j.neuron.2014.12.007

53. Ramirez A, Heimbach A, Gründemann J, Stiller B, Hampshire D, Cid LP, et al. Hereditary parkinsonism with dementia is caused by mutations in ATP13A2, encoding a lysosomal type 5 P-type ATPase. Nat Genet. 2006 Oct;38(10):1184-91. https://doi.org/10.1038/ng1884

54. Paisan-Ruiz C, Bhatia KP, Li A, Hernandez D, Davis M, Wood NW, et al. Characterization of PLA2G6 as a locus for dystonia-parkinsonism. Ann Neurol. 2009 Jan;65(1):19-23. https://doi.org/10.1002/ ana. 21415

55. Di Fonzo A, Dekker MCJ, Montagna P, Baruzzi A, Yonova EH, Correia Guedes L, et al. FBXO7 mutations cause autosomal recessive, early-onset parkinsonian-pyramidal syndrome. Neurology. 2009 Jan 20;72(3):240-5. https://doi.org/10.1212/01.wnl.0000338144.10967.2b

56. Olgiati S, Quadri M, Fang M, Rood JPMA, Saute JA, Chien HF, et al. DNAJC6 mutations associated with early-onset Parkinson's disease. Ann Neurol. 2016 Feb 1;79(2):244-56. https://doi.org/10.1002/ ana. 24553 
57. Puschmann A, Ross OA, Vilariño-Güell C, Lincoln SJ, Kachergus JM, Cobb SA, et al. A Swedish family with de novo alpha-synuclein A53T mutation: Evidence for early cortical dysfunction. Parkinsonism Relat Disord. 2009 Nov;15(9):627-32. https://doi.org/10.1016/j.parkreldis.2009.06.007

58. Kitada T, Asakawa S, Hattori N, Matsumine H, Yamamura Y, Minoshima S, et al. Mutations in the parkin gene cause autosomal recessive juvenile parkinsonism. Nature. 1998 Apr 9;392(6676):605-8. https://doi.org/10.1038/33416

59. Nishikawa K, Li H, Kawamura R, Osaka H, Wang Y-L, Hara Y, et al. Alterations of structure and hydrolase activity of parkinsonism-associated human ubiquitin carboxyl-terminal hydrolase L1 variants. Biochem Biophys Res Commun. 2003 Apr 25;304(1):176-83. https://doi.org/10.1016/ S0006-291X(03)00555-2

60. Valente EM, Salvi S, Ialongo T, Marongiu R, Elia AE, Caputo V, et al. PINKI mutations are associated with sporadic early-onset parkinsonism. Ann Neurol. 2004 Sep;56(3):336-41. https://doi. org/10.1002/ana.20256

61. Bonifati V, Rizzu P, van Baren MJ, Schaap O, Breedveld GJ, Krieger E, et al. Mutations in the DJ-1 gene associated with autosomal recessive early-onset parkinsonism. Science. 2003 Jan 10;299(5604): 256-9. https://doi.org/10.1126/science.1077209

62. Zimprich A, Biskup S, Leitner P, Lichtner P, Farrer M, Lincoln S, et al. Mutations in LRRK2 cause autosomal-dominant parkinsonism with pleomorphic pathology. Neuron. 2004 Nov 18;44(4):601-7. https://doi.org/10.1016/j.neuron.2004.11.005

63. Williams DR, Hadeed A, al-Din ASN, Wreikat A-L, Lees AJ. Kufor Rakeb disease: Autosomal recessive, levodopa-responsive parkinsonism with pyramidal degeneration, supranuclear gaze palsy, and dementia. Mov Disord. 2005 Oct;20(10):1264-71. https://doi.org/10.1002/mds.20511

64. Lautier C, Goldwurm S, Dürr A, Giovannone B, Tsiaras WG, Pezzoli G, et al. Mutations in the GIGYF2 (TNRC15) gene at the PARK11 locus in familial Parkinson disease. Am J Hum Genet. 2008 Apr;82(4):822-33. https://doi.org/10.1016/j.ajh.2008.01.015

65. Strauss KM, Martins LM, Plun-Favreau H, Marx FP, Kautzmann S, Berg D, et al. Loss of function mutations in the gene encoding Omi/HtrA2 in Parkinson's disease. Hum Mol Genet. 2005 Aug 1;14(15):2099-111. https://doi.org/10.1093/hmg/ddi215

66. Wider C, Skipper L, Solida A, Brown L, Farrer M, Dickson D, et al. Autosomal dominant doparesponsive parkinsonism in a multigenerational Swiss family. Parkinsonism Relat Disord. 2008 Aug;14(6):465-70. https://doi.org/10.1016/j.parkreldis.2007.11.013

67. Chartier-Harlin M-C, Dachsel JC, Vilariño-Güell C, Lincoln SJ, Leprêtre F, Hulihan MM, et al. Translation initiator EIF4Gl mutations in familial Parkinson disease. Am J Hum Genet. $2011 \mathrm{Sep}$ 9;89(3):398-406. https://doi.org/10.1002/humu.22373

68. Quadri M, Fang M, Picillo M, Olgiati S, Breedveld GJ, Graafland J, et al. Mutation in the SYNJI gene associated with autosomal recessive, early-onset Parkinsonism. Hum Mutat. 2013 Sep;34(9): 1208-15. https://doi.org/10.1002/humu.22373

69. Vilariño-Güell C, Rajput A, Milnerwood AJ, Shah B, Szu-Tu C, Trinh J, et al. DNAJC13 mutations in Parkinson disease. Hum Mol Genet. 2014 Apr 1;23(7):1794-801. https://doi.org/10.1093/hmg/ ddt570

70. Lesage S, Drouet V, Majounie E, Deramecourt V, Jacoupy M, Nicolas A, et al. Loss of VPS13C function in autosomal-recessive Parkinsonism causes mitochondrial dysfunction and increases PINK1/Parkindependent Mitophagy. Am J Hum Genet. 2016 Mar 3;98(3):500-13. https://doi.org/10.1016/j. ajhg.2016.01.014

71. Dickson DW. Parkinson's disease and Parkinsonism: Neuropathology. Cold Spring Harb Perspect Med. 2012 Aug 1;2(8):a009258. https://doi.org/10.1101/cshperspect.a009258

72. Fearnley JM, Lees AJ. Ageing and Parkinson's disease: Substantia nigra regional selectivity. Brain. 1991 Oct;114 ( Pt 5):2283-301. https://doi.org/10.1093/brain/114.5.2283

73. Greffard S, Verny M, Bonnet A-M, Beinis J-Y, Gallinari C, Meaume S, et al. Motor score of the unified Parkinson disease rating scale as a good predictor of Lewy body-associated neuronal loss in the substantia nigra. Arch Neurol. 2006 Apr;63(4):584-8. https://doi.org/10.1001/archneur.63.4.584

74. Cheng H-C, Ulane CM, Burke RE. Clinical progression in Parkinson's disease and the neurobiology of axons. Ann Neurol. 2010 Jun;67(6):715-25. https://doi.org/10.1002/ana.21995 
75. Rudow G, O'Brien R, Savonenko AV, Resnick SM, Zonderman AB, Pletnikova O, et al. Morphometry of the human substantia nigra in ageing and Parkinson's disease. Acta Neuropathol. 2008 Feb 23;115(4):461. https://doi.org/10.1007/s00401-008-0352-8

76. Giguère N, Burke Nanni S, Trudeau L-E. On cell loss and selective vulnerability of neuronal populations in Parkinson's disease. Front Neurol [Internet]. 2018 [cited 2018 Oct 18];9. Available from: https://www.frontiersin.org/articles/10.3389/fneur.2018.00455/full

77. Kordower JH, Olanow CW, Dodiya HB, Chu Y, Beach TG, Adler CH, et al. Disease duration and the integrity of the nigrostriatal system in Parkinson's disease. Brain. 2013 Aug 1;136(8):2419-31. https:// doi.org/10.1093/brain/awt192

78. Kalia LV, Brotchie JM, Fox SH. Novel nondopaminergic targets for motor features of Parkinson's disease: Review of recent trials. Mov Disord. 2013 Feb 1;28(2):131-44. https://doi.org/10.1002/ mds. 25273

79. Chaudhuri KR, Healy DG, Schapira AH. Non-motor symptoms of Parkinson's disease: Diagnosis and management. Lancet Neurol. 2006 Mar;5(3):235-45. https://doi.org/10.1016/S1474-4422 (06)70373-8

80. Spillantini MG, Schmidt ML, Lee VM, Trojanowski JQ, Jakes R, Goedert M. Alpha-synuclein in Lewy bodies. Nature. 1997 Aug 28;388(6645):839-40. https://doi.org/10.1038/42166

81. Spillantini MG, Crowther RA, Jakes R, Hasegawa M, Goedert M. $\alpha$-Synuclein in filamentous inclusions of Lewy bodies from Parkinson's disease and dementia with Lewy bodies. Proc Natl Acad Sci U S A. 1998 May 26;95(11):6469-73. https://doi.org/10.1073/pnas.95.11.6469

82. Goedert M, Spillantini MG, Del Tredici K, Braak H. 100 years of Lewy pathology. Nat Rev Neurol. 2012 Nov 27;9(1):13-24. https://doi.org/10.1038/nrneurol.2012.242

83. Xia Q, Liao L, Cheng D, Duong DM, Gearing M, Lah JJ, et al. Proteomic identification of novel proteins associated with Lewy bodies. Front Biosci. 2008 May 1;13:3850-6. https://doi.org/10.2741/2973

84. Braak H, Del Tredici K, Rüb U, de Vos RA, Steur ENJ, Braak E. Staging of brain pathology related to sporadic Parkinson's disease. Neurobiol Aging. 2003;24(2):197-211. https://doi.org/10.1016/ S0197-4580(02)00065-9

85. Chaudhuri KR, Schapira AH. Non-motor symptoms of Parkinson's disease: Dopaminergic pathophysiology and treatment. Lancet Neurol. 2009 May;8(5):464-74. https://doi.org/10.1016/ S1474-4422(09)70068-7

86. Khoo TK, Yarnall AJ, Duncan GW, Coleman S, O'Brien JT, Brooks DJ, et al. The spectrum of nonmotor symptoms in early Parkinson disease. Neurology. 2013 Jan 15;80(3):276-81. https://doi.org/10.1212/ WNL.0b013e31827deb74

87. Pavese N, Rivero-Bosch M, Lewis SJ, Whone AL, Brooks DJ. Progression of monoaminergic dysfunction in Parkinson's disease: A longitudinal 18F-dopa PET study. Neuroimage. 2011 Jun 1;56(3): 1463-8. https://doi.org/10.1016/j.neuroimage.2011.03.012

88. Hawkes CH, Tredici KD, Braak H. Parkinson's disease: A dual-hit hypothesis. Neuropathol Appl Neurobiol. 2007 Dec 1;33(6):599-614. https://doi.org/10.1111/j.1365-2990.2007.00874.x

89. Parkkinen L, Pirttilä T, Alafuzoff I. Applicability of current staging/categorization of $\alpha$-synuclein pathology and their clinical relevance. Acta Neuropathol. 2008 Apr 1;115(4):399-407. https://doi. org/10.1007/s00401-008-0346-6

90. Kalaitzakis ME, Graeber MB, Gentleman SM, Pearce RKB. The dorsal motor nucleus of the vagus is not an obligatory trigger site of Parkinson's disease: A critical analysis of $\alpha$-synuclein staging. Neuropathol Appl Neurobiol. 2008 Jun 1;34(3):284-95. https://doi.org/10.1111/j.1365-2990.2007.00923.x

91. Jellinger KA. A critical evaluation of current staging of alpha-synuclein pathology in Lewy body disorders. Biochim Biophys Acta. 2009 Jul;1792(7):730-40. https://doi.org/10.1016/j.bbadis.2008.07.006

92. Surmeier DJ, Obeso JA, Halliday GM. Parkinson's disease is not simply a prion disorder. J Neurosci. 2017 Oct 11;37(41):9799-807. https://doi.org/10.1523/JNEUROSCI.1787-16.2017

93. Bloch A, Probst A, Bissig H, Adams H, Tolnay M. $\alpha$-Synuclein pathology of the spinal and peripheral autonomic nervous system in neurologically unimpaired elderly subjects. Neuropathol Appl Neurobiol. 2006 Jun 1;32(3):284-95. https://doi.org/10.1111/j.1365-2990.2006.00727.x

94. Beach TG, Adler CH, Sue LI, Vedders L, Lue L, White III CL, et al. Multi-organ distribution of phosphorylated $\alpha$-synuclein histopathology in subjects with Lewy body disorders. Acta Neuropathol. 2010 Jun 1;119(6):689-702. https://doi.org/10.1007/s00401-010-0664-3 
95. Beach TG, Carew J, Serrano G, Adler CH, Shill HA, Sue LI, et al. Phosphorylated $\alpha$-synucleinimmunoreactive retinal neuronal elements in Parkinson's disease subjects. Neurosci Lett. 2014 Jun 13;571:34-8. https://doi.org/10.1016/j.neulet.2014.04.027

96. Svensson E, Horváth-Puhó E, Thomsen RW, Djurhuus JC, Pedersen L, Borghammer P, et al. Vagotomy and subsequent risk of Parkinson's disease. Ann Neurol. 2015 Oct 1;78(4):522-9. https://doi. org/10.1002/ana.24448

97. Perez-Pardo P, Kliest T, Dodiya HB, Broersen LM, Garssen J, Keshavarzian A, et al. The gut-brain axis in Parkinson's disease: Possibilities for food-based therapies. Eur J Pharmacol. 2017 Dec 15;817: 86-95. https://doi.org/10.1016/j.ejphar.2017.05.042

98. Jellinger KA, Popescu B. Interaction between pathogenic proteins in neurodegenerative disorders. J Cell Mol Med. 2012 Jun;16(6):1166-83. https://doi.org/10.1111/j.1582-4934.2011.01507.x

99. Elobeid A, Libard S, Leino M, Popova SN, Alafuzoff I. Altered proteins in the aging brain. J Neuropathol Exp Neurol. 2016 Apr;75(4):316-25. https://doi.org/10.1093/jnen/nlw002

100. Wills J, Jones J, Haggerty T, Duka V, Joyce JN, Sidhu A. Elevated tauopathy and alpha-synuclein pathology in postmortem Parkinson's disease brains with and without dementia. Exp Neurol. 2010 Sep;225(1):210-18. https://doi.org/10.1016/j.expneurol.2010.06.017

101. Duka T, Sidhu A. The neurotoxin, MPP+, induces hyperphosphorylation of Tau, in the presence of $\alpha$-Synuclein, in SH-SY5Y neuroblastoma cells. Neurotox Res. 2006 Mar;10(1):1-10.

102. Duka T, Rusnak M, Drolet RE, Duka V, Wersinger C, Goudreau JL, et al. Alpha-synuclein induces hyperphosphorylation of Tau in the MPTP model of parkinsonism. FASEB J. 2006 Nov; 20(13):2302-12. https://doi.org/10.1096/fj.06-6092com

103. Goris A, Williams-Gray CH, Clark GR, Foltynie T, Lewis SJG, Brown J, et al. Tau and $\alpha$-synuclein in susceptibility to, and dementia in, Parkinson's disease. Ann Neurol. 2007 Aug;62(2):145-53. https:// doi.org/10.1002/ana.21192

104. Lashley T, Holton JL, Gray E, Kirkham K, O'Sullivan SS, Hilbig A, et al. Cortical alpha-synuclein load is associated with amyloid-beta plaque burden in a subset of Parkinson's disease patients. Acta Neuropathol. 2008 Apr;115(4):417-25. https://doi.org/10.1007/s00401-007-0336-0

105. Pletnikova O, West N, Lee MK, Rudow GL, Skolasky RL, Dawson TM, et al. A $\beta$ deposition is associated with enhanced cortical $\alpha$-synuclein lesions in Lewy body diseases. Neurobiol Aging. 2005 Aug;26(8):1183-92. https://doi.org/10.1016/j.neurobiolaging.2004.10.006

106. Kalaitzakis ME, Graeber MB, Gentleman SM, Pearce RKB. Striatal $\beta$-Amyloid deposition in Parkinson disease with dementia. J Neuropathol Exp Neurol. 2008 Feb 1;67(2):155-61. https://doi.org/10.1097/ NEN.0b013e31816362aa

107. Compta Y, Parkkinen L, O'Sullivan SS, Vandrovcova J, Holton JL, Collins C, et al. Lewy- and Alzheimer-type pathologies in Parkinson's disease dementia: Which is more important? Brain. 2011 May 1;134(5):1493-505. https://doi.org/10.1093/brain/awr031

108. Ruffmann C, Calboli FCF, Bravi I, Gveric D, Curry LK, de Smith A, et al. Cortical Lewy bodies and A $\beta$ burden are associated with prevalence and timing of dementia in Lewy body diseases. Neuropathol Appl Neurobiol. 2016 Aug;42(5):436-50.

109. Burré J, Vivona S, Diao J, Sharma M, Brunger AT, Südhof TC. Properties of native brain $\alpha$-synuclein. Nature. 2013 Jun;498(7453):E4-6. https://doi.org/10.1038/nature12125

110. Bartels T, Choi JG, Selkoe DJ. $\alpha$-Synuclein occurs physiologically as a helically folded tetramer that resists aggregation. Nature. 2011 Sep;477(7362):107-10. https://doi.org/10.1038/nature10324

111. Eliezer D, Kutluay E, Bussell R, Browne G. Conformational properties of $\alpha$-synuclein in its free and lipid-associated states11Edited by P. E. Wright. J Mol Biol. 2001 Apr 6;307(4):1061-73.

112. Fujiwara H, Hasegawa M, Dohmae N, Kawashima A, Masliah E, Goldberg MS, et al. alpha-Synuclein is phosphorylated in synucleinopathy lesions. Nat Cell Biol. 2002 Feb;4(2):160-4. https://doi. org/10.1038/ncb748

113. Barrett PJ, Timothy Greenamyre J. Post-translational modification of $\alpha$-synuclein in Parkinson's disease. Brain Res. 2015 Dec 2;1628(Pt B):247-53.

114. Baba M, Nakajo S, Tu PH, Tomita T, Nakaya K, Lee VM, et al. Aggregation of alpha-synuclein in Lewy bodies of sporadic Parkinson's disease and dementia with Lewy bodies. Am J Pathol. 1998 Apr;152(4):879-84. 
115. Winner B, Jappelli R, Maji SK, Desplats PA, Boyer L, Aigner S, et al. In vivo demonstration that -synuclein oligomers are toxic. Proc Natl Acad Sci. 2011 Mar 8;108(10):4194-9. https://doi.org/10.1073/ pnas. 1100976108

116. Karpinar DP, Balija MBG, Kügler S, Opazo F, Rezaei-Ghaleh N, Wender N, et al. Pre-fibrillar $\alpha$-synuclein variants with impaired $\beta$-structure increase neurotoxicity in Parkinson's disease models. EMBO J. 2009 Oct 21;28(20):3256-68. https://doi.org/10.1038/emboj.2009.257

117. Danzer KM, Krebs SK, Wolff M, Birk G, Hengerer B. Seeding induced by $\alpha$-synuclein oligomers provides evidence for spreading of $\alpha$-synuclein pathology. J Neurochem. 2009 Oct 1;111(1):192-203. https://doi.org/10.1111/j.1471-4159.2009.06324.x

118. Moon HE, Paek SH. Mitochondrial dysfunction in Parkinson's disease. Exp Neurobiol. 2015 Jun;24(2):103-16. https://doi.org/10.5607/en.2015.24.2.103

119. Schapira AH, Cooper JM, Dexter D, Clark JB, Jenner P, Marsden CD. Mitochondrial complex I deficiency in Parkinson's disease. J Neurochem. 1990 Mar;54(3):823-7. https://doi. org/10.1111/j.1471-4159.1990.tb02325.x

120. Bindoff LA, Birch-Machin MA, Cartlidge NEF, Parker WD, Turnbull DM. Respiratory chain abnormalities in skeletal muscle from patients with Parkinson's disease. J Neurol Sci. 1991 Aug 1;104(2):203-8. https://doi.org/10.1016/0022-510X(91)90311-T

121. Krige D, Carroll MT, Cooper JM, Marsden CD, Schapira AH. Platelet mitochondrial function in Parkinson's disease. The Royal Kings and Queens Parkinson Disease Research Group. Ann Neurol. 1992 Dec;32(6):782-8. https://doi.org/10.1002/ana.410320612

122. Langston JW, Forno LS, Tetrud J, Reeves AG, Kaplan JA, Karluk D, et al. Evidence of active nerve cell degeneration in the substantia nigra of humans years after 1-methyl-4-phenyl-1, 2, 3, 6-tetrahydropyridine exposure. Ann Neurol. 1999;46(4):598-605. https://doi.org/10.1002/15318249(199910)46:4\%3C598::AID-ANA7\%3E3.0.CO;2-F

123. Nicklas WJ, Vyas I, Heikkila RE. Inhibition of NADH-linked oxidation in brain mitochondria by 1-methyl-4-phenyl-pyridine, a metabolite of the neurotoxin, 1-methyl-4-phenyl-1,2,5,6-tetrahydropyridine. Life Sci. 1985 Jul 1;36(26):2503-8. https://doi.org/10.1016/0024-3205(85)90146-8

124. Tanner CM, Kamel F, Ross GW, Hoppin JA, Goldman SM, Korell M, et al. Rotenone, paraquat, and Parkinson's disease. Environ Health Perspect. 2011 Jun 1;119(6):866-72. https://doi.org/10.1289/ ehp. 1002839

125. Valente EM, Bentivoglio AR, Dixon PH, Ferraris A, Ialongo T, Frontali M, et al. Localization of a novel locus for autosomal recessive early-onset Parkinsonism, PARK6, on human chromosome lp35-p36. Am J Hum Genet. 2001 Apr;68(4):895-900. https://doi.org/10.1086/319522

126. Devi L, Raghavendran V, Prabhu BM, Avadhani NG, Anandatheerthavarada HK. Mitochondrial import and accumulation of $\alpha$-Synuclein impair complex I in human dopaminergic neuronal cultures and Parkinson disease brain. J Biol Chem. 2008 Apr 4;283(14):9089-100. https://doi.org/10.1074/jbc. M710012200

127. Luth ES, Stavrovskaya IG, Bartels T, Kristal BS, Selkoe DJ. Soluble, prefibrillar $\alpha$-Synuclein oligomers promote complex I-dependent, Ca2+-induced mitochondrial dysfunction. J Biol Chem. 2014 Aug 1;289(31):21490-507. https://doi.org/10.1074/jbc.M113.545749

128. Maio RD, Barrett PJ, Hoffman EK, Barrett CW, Zharikov A, Borah A, et al. $\alpha$-Synuclein binds to TOM20 and inhibits mitochondrial protein import in Parkinson's disease. Sci Transl Med. 2016 Jun 8;8(342):342ra78.

129. Pan T, Kondo S, Le W, Jankovic J. The role of autophagy-lysosome pathway in neurodegeneration associated with Parkinson's disease. Brain. 2008 Aug 1;131(8):1969-78. https://doi.org/10.1093/ brain/awm 318

130. Xilouri M, Brekk OR, Stefanis L. Alpha-synuclein and protein degradation systems: A reciprocal relationship. Mol Neurobiol. 2013 Apr 1;47(2):537-51. https://doi.org/10.1007/s12035-012-8341-2

131. Ebrahimi-Fakhari D, Wahlster L, McLean PJ. Protein degradation pathways in Parkinson's disease: Curse or blessing. Acta Neuropathol. 2012 Aug 1;124(2):153-72. https://doi.org/10.1007/ s00401-012-1004-6

132. Lee H-J, Khoshaghideh F, Patel S, Lee S-J. Clearance of alpha-synuclein oligomeric intermediates via the lysosomal degradation pathway. J Neurosci. 2004 Feb 25;24(8):1888-96. https://doi.org/10.1523/ JNEUROSCI.3809-03.2004 
133. McKinnon C, Tabrizi SJ. The Ubiquitin-Proteasome system in neurodegeneration. Antioxidants Redox Signaling. 2014 Jan 18;21(17):2302-21. https://doi.org/10.1089/ars.2013.5802

134. McNaught KSP, Jenner P. Proteasomal function is impaired in substantia nigra in Parkinson's disease. Neurosci Lett. 2001 Jan 19;297(3):191-4. https://doi.org/10.1016/S0304-3940(00)01701-8

135. Ullrich C, Mlekusch R, Kuschnig A, Marksteiner J, Humpel C. Ubiquitin enzymes, ubiquitin and proteasome activity in blood mononuclear cells of MCI, Alzheimer and Parkinson patients. Curr Alzheimer Res. 2010 Sep;7(6):549-55. https://doi.org/10.2174/156720510792231766

136. McNaught KSP, Belizaire R, Jenner P, Olanow CW, Isacson O. Selective loss of $20 \mathrm{~S}$ proteasome alpha-subunits in the substantia nigra pars compacta in Parkinson's disease. Neurosci Lett. 2002 Jul 5;326(3):155-8. https://doi.org/10.1016/S0304-3940(02)00296-3

137. McNaught KSP, Belizaire R, Isacson O, Jenner P, Olanow CW. Altered proteasomal function in sporadic Parkinson's disease. Exp Neurol. 2003 Jan;179(1):38-46. https://doi.org/10.1006/exnr.2002.8050

138. Um JW, Im E, Lee HJ, Min B, Yoo L, Yoo J, et al. Parkin directly modulates $26 S$ proteasome activity. J Neurosci. 2010 Sep 1;30(35):11805-14. https://doi.org/10.1523/JNEUROSCI.2862-09.2010

139. Zeng B-Y, Iravani MM, Lin S-T, Irifune M, Kuoppamäki M, Al-Barghouthy G, et al. MPTP treatment of common marmosets impairs proteasomal enzyme activity and decreases expression of structural and regulatory elements of the $26 \mathrm{~S}$ proteasome. Eur J Neurosci. 2006 Apr;23(7):1766-74. https://doi. org/10.1111/j.1460-9568.2006.04718.x

140. Zeng B-Y, Bukhatwa S, Hikima A, Rose S, Jenner P. Reproducible nigral cell loss after systemic proteasomal inhibitor administration to rats. Ann Neurol. 2006 Aug;60(2):248-52. https://doi.org/10.1002/ ana.20932

141. Bedford L, Hay D, Devoy A, Paine S, Powe DG, Seth R, et al. Depletion of 26S Proteasomes in mouse brain neurons causes neurodegeneration and Lewy-like inclusions resembling human pale bodies. J Neurosci. 2008 Aug 13;28(33):8189-98. https://doi.org/10.1523/JNEUROSCI.2218-08.2008

142. Tanji K, Mori F, Kakita A, Takahashi H, Wakabayashi K. Alteration of autophagosomal proteins (LC3, GABARAP and GATE-16) in Lewy body disease. Neurobiol Dis. 2011 Sep 1;43(3):690-7. https://doi. org/10.1016/j.nbd.2011.05.022

143. Dehay B, Bove J, Rodriguez-Muela N, Perier C, Recasens A, Boya P, et al. Pathogenic lysosomal depletion in Parkinson's disease. J Neurosci. 2010 Sep 15;30(37):12535-44. https://doi.org/10.1523/ JNEUROSCI.1920-10.2010

144. Chu Y, Dodiya H, Aebischer P, Olanow CW, Kordower JH. Alterations in lysosomal and proteasomal markers in Parkinson's disease: Relationship to alpha-synuclein inclusions. Neurobiol Dis. 2009 Sep;35(3):385-98. https://doi.org/10.1016/j.nbd.2009.05.023

145. Alvarez-Erviti L, Rodriguez-Oroz MC, Cooper JM, Caballero C, Ferrer I, Obeso JA, et al. Chaperonemediated autophagy markers in Parkinson disease brains. Arch Neurol. 2010 Dec;67(12):1464-72. https://doi.org/10.1001/archneurol.2010.198

146. McGeer PL, Itagaki S, Boyes BE, McGeer EG. Reactive microglia are positive for HLA-DR in the substantia nigra of Parkinson's and Alzheimer's disease brains. Neurology. 1988 Aug;38(8):1285-91. https://doi.org/10.1212/WNL.38.8.1285

147. Hunot S, Dugas N, Faucheux B, Hartmann A, Tardieu M, Debré P, et al. FceRII/CD23 is expressed in Parkinson's disease and induces, in vitro, production of nitric oxide and tumor necrosis factor- $\alpha$ in Glial cells. J Neurosci. 1999 May 1;19(9):3440-7. https://doi.org/10.1523/ JNEUROSCI.19-09-03440.1999

148. Loeffler DA, Camp DM, Conant SB. Complement activation in the Parkinson's disease substantia nigra: An immunocytochemical study. J Neuroinflammation. 2006;3:29. https://doi.org/10.1186/ 1742-2094-3-29

149. Hirsch EC, Hunot S. Neuroinflammation in Parkinson's disease: A target for neuroprotection? Lancet Neurol. 2009;8(4):382-97. https://doi.org/10.1016/S1474-4422(09)70062-6

150. Gerhard A, Pavese N, Hotton G, Turkheimer F, Es M, Hammers A, et al. In vivo imaging of microglial activation with [11C](R)-PK11195 PET in idiopathic Parkinson's disease. Neurobiol Dis. 2006 Feb;21(2):404-12. https://doi.org/10.1016/j.nbd.2005.08.002

151. Edison P, Ahmed I, Fan Z, Hinz R, Gelosa G, Chaudhuri KR, et al. Microglia, amyloid, and glucose metabolism in Parkinson's disease with and without dementia. Neuropsychopharmacology. 2013;38(6):938-49. https://doi.org/10.1038/npp.2012.255 


\section{Etiology and Pathogenesis}

152. He Y, Appel S, Le W. Minocycline inhibits microglial activation and protects nigral cells after 6-hydroxydopamine injection into mouse striatum. Brain Res. 2001 Aug 3;909(1-2):187-93. https:// doi.org/10.1016/S0006-8993(01)02681-6

153. Jackson-Lewis V, Vila M, Tieu K, Teismann P, Vadseth C, Choi D-K, et al. Blockade of microglial activation is neuroprotective in the 1-methyl-4-phenyl-1, 2, 3, 6-tetrahydropyridine mouse model of Parkinson disease. J Neurosci. 2002;22(5):1763-71.

154. Su X, Maguire-Zeiss KA, Giuliano R, Prifti L, Venkatesh K, Federoff HJ. Synuclein activates microglia in a model of Parkinson's disease. Neurobiol Aging. 2008 Nov;29(11):1690-701.

155. Saiki M, Baker A, Williams-Gray CH, Foltynie T, Goodman RS, Taylor CJ, et al. Association of the human leucocyte antigen region with susceptibility to Parkinson's disease. J Neurol Neurosurg Psychiatr. 2010 Aug 1;81(8):890-1.

156. Gao X, Chen H, Schwarzschild MA, Ascherio A. Use of ibuprofen and risk of Parkinson disease. Neurology. 2011;76(10):863-9.

157. Williams-Gray CH, Wijeyekoon R, Yarnall AJ, Lawson RA, Breen DP, Evans JR, et al. Serum immune markers and disease progression in an incident Parkinson's disease cohort (ICICLE-PD). Mov Disord. 2016 Jul 1;31(7):995-1003. 